\title{
NYELVI ANTROPOLÓGIA
}

A szerző az 1956. évi forradalom után került szüleivel az Egyesült Államokba, 1994-től a University of Chicago professzora, kutatási területe az antropológia és a nyelvészet. A könyv előszavában angolul és magyarul olvasható Susan Gal bevezetője, amelyben elmondja életéről és munkásságáról mindazt, amit fontosnak tart a magyar olvasó számára. Ezután a kötet egyik szerkesztője, Vančo Ildikó ír a chicagói nyelvész tudományos munkásságáról, tanulmányainak tematikájáról, továbbá a kötet létrejöttéről. A könyv végén pedig interjú olvasható, amelyet Kontra Miklós készített Gál Zsuzsával 2014-ben a Nyitrán rendezett, 18. Élőnyelvi Konferencia alkalmával. Lezárásként ugyancsak a Kontra Miklós tollából származó utószó áll, ebben az életrajz-életpálya vázolása mellett a tudós négy évtizedes szakmai tevékenységét méltatja. A kötetnek ez a két része jól eligazítja az olvasót Susan Gal munkássága, nézetrendszere tekintetében.

A kiadványban tizenhárom tanulmány sorakozik három csoportba osztva: az első csoport címe „Nyelvi antropológiai elmélet”.

A nyelv és a politikai terek címü tanulmány kimutatja, hogy a helynevek elvesztése politikai változások indexikus jele is lehet. A magyarországi földek ún. kollektivizálása révén a szántóföldek, erdők, mezők ősi neveit nem használhatta a nép. Majd a rendszerváltozás után hiába állítódott vissza a magántulajdon, ,[a] nyolcvan évesnél fiatalabb férfiak és nők talán hallották az archaikus kifejezéseket, de már nem tudják azokat arra használni, hogy utaljanak velük arra a földre, amely visszakapta korábbi értékét” (51.). Ez a dolgozat is mutatja, hogy Susan Gal összekapcsolja a társadalmi változások, helyzetek, állapotok leírását a nyelvhasználat egyes tulajdonságaival. Így egy-egy nyelvi jelenség bizonyítja vagy segíti bizonyítani a társadalomra vagy valamely csoportjára vonatkozó megfigyeléseit. A standard nyelv ellentmondásai Európában tárgyköréről szóló tanulmány abból az általános nézetből indul ki, amelyik szerint az egyes nyelvek rendszere egy nemzet által megszervezett rendszer, amely e nemzet és az általa elfoglalt terület szellemét fejezi ki. Ez láttatja természetesnek az egynyelvüséget. A standard rendszerek a bennük élők számára tekintélyt jelentenek, a többi nyelvi alak nem tünik helyénvalónak (56.). A szerző a standard nyelvnek különféle ellentmondásait mutatja be: kisebbségek, diaszpórában élők (oberwarti, azaz felsőőri, bólyi magyar és más), beszélők nyelvi jelenségeivel, állapotával szemléltetve. A standard nyelv - mondja a szerző - korántsem kiemelkedő fontosságú tényező az üzenetek körforgásában (69.). A szöveges üzenetek vagy metanyelvi üzenetek körforgásának példája egy dániai népszavazásról szóló dán, angol és más (sajtó)beszámolókban megjelenő nézetek (re)kontextuálása. „A standard ideológia általános jelenlé- 
te elrejti a kutatók és az elitek elől egy specifikus nyilvánosság felbukkanását, a politikai vita nyelveken átívelő csatornáit" - véli a tanulmányíró.

A beszéd izei: kvália és a jelek morális aromája címü tanulmány a Charles Sanders Peirce szemiotikájából való kváliák egyes társadalmi vonatkozását elemzi. Például az „egyenes beszéd”, az „érdes német”, a ,jázmin illatú tamil” szerkezetek mutatják, hogy e metaforikus kifejezések elvont tulajdonságokat érzékszervvel tapasztalható kapcsolattal (kvália) mondanak valamit a nyelvről, illetőleg egy nép nyelvéröl.

A magyar kváliájáról Rákosi Jenő (1848-1929) általánosan elterjedt nézeteket fejtett ki, népszerüsített. A 19. század végéről származó egyik írásában a némethez és az olaszhoz hasonlítva nem cifrának, méltóságos tempójúnak, nyugodtnak, logikusnak és voltaképp magasabb rendünek tartotta, mondván, hogy nincsenek benne váltakozó hangsúlyminták, hiszen méltóságos rendben követik az első szót, a magyar magánhangzók is tiszták, hiszen nincsenek „,kétségbe ejtő” variációk, a szavakon belül illenek egymáshoz, a ragozási mintázatok a magyar nyugodtságát jelzik, míg a német és az olasz igék ,csavarodottak”, megtörik a szó tövét stb. Susan Gal Bólyban (Bohl) a 'palacsinta' és a 'Pfannkucha' szavak használata révén mutatja be az efféle jelenséget Bóly (Bohl) községben, ahol a lakosság egy része kétnyelvü. A társadalmi helyzetének megfelelőn (Bäuerisch regiszterben, a gazdag paraszt tipizált jellegzetes hangján szólva) az adatközlő szerint a magyar „palacsinta” (az iparos réteg nyelvhasználata szerint) túl cifra, ezért használja a Pfannkucha szót, amely sürübb és vastagabb, mint a palacsinta (mármint étel). E szóhasználat példázza a szociális csoporthoz való tartozás kifejeződését egy kváliajelenség kapcsán.

„Tanulmányok a nyelv variáció területéről (a Kárpát-medencében)” a címe a második tanulmánycsoportnak. Ez a magyarországi németség 18. századi megérkezésétől vázolja e népcsoport történetét, majd bemutatja, hogy Bóly közösségében a státus és a szolidaritás alapján különbözött a nyelvmegtartás gyakorlata az idők folyamán. Az 1980 utáni években családi vagy egyéb kapcsolatok révén számosan Nyugat-Németországban vállaltak munkát, német nyelvtudásuk így „erőteljes és burkolt bírálata a szocializmusnak: újraértékeli a kettő közötti összehasonlítást, és páneurópai, gazdaságpolitikai színtérre emeli azt, amelyben a magyar gyengébb a német nyelvnél, annak ellenére, hogy előbbi az államnyelv" (150.).

Susan Gal olyan klasszikus tanulmánya, a Mi a nyelvcsere és hogyan történik? címủ, amely egyetlen, a nyelv változásával, a nyelv természetével foglalkozó tanulmánygyüjteményből sem hiányozhat - írja a szerkesztők egyike, Vančo Ildikó (24.). E dolgozat eredetije már 1992-ben megjelent az MTA Nyelvtudományi Intézetének egyik kiadványában. A nyelvcsere folyamatának fö példája Felsőőr (Oberwart) 1974-beli és azutáni nyelvállapota, illetőleg az ottani társadalom helyzete Burgenlandban. Természetesen a beszélők nem társadalmi státusuktól, életkoruktól, munkájuktól, családi kapcsolataiktól függetlenül hagyják el a magyart, azonban nyelvhasználatukban a családi, társadalmi, kulturális és jövedelmi tényezők a némettel mutatnak szolidaritást. Mindez nyelvészeti vizsgálatok nélkül 
is tudható és belátható, a szerző érdeme, hogy nyelvi jelenségek - szókincs, szóképzés, vonzatszerkezetek és így tovább - elemzésével bizonyít. Voltaképpen ez a szociolingvisztika alapja, módszere.

Ettől az eljárástól eltérö tanulmány (a harmadik fejezetben) a Bartók Béla temetése: Európa-kép a magyar politikai retorikában című. Amint a szerző írja: „A Bartók-temetés exegézise beleillik a tágan értelmezett antropológiai elemzések - eseményfeldolgozások - csoportjába" (233.). A zeneszerző 1988. évi itthoni újratemetése elötti magyar történelemnek, illetőleg Kelet-Európa állapota áttekintésének alapján Susan Gal a korabeli magyar sajtó temetéssel kapcsolatos írásainak bőségét említve megállapítja az 1988-ban még létező szocializmussal kapcsolatos mitikusság megjelenését. Az államszocializmus képviselöi egy általuk kívánatos Bartók-képet igyekeztek alkotni, míg sok ember elutasította a retorika ilyetén eredményét. Ugyanakkor valamelyest sikerült azt az érzetet kelteni, hogy Magyarország és Európa közel került egymáshoz, sőt Románia is, minthogy kiaknázták volt Bartók Béla munkásságának román vonatkozásait (254-255.). Fontos megállapítása a szerzőnek, hogy az efféle retorikai folyamatok, mint amelyeket a Bartók-temetés kapcsán föltárt, a kapitalista és a szocialista társadalmakban egyaránt megtalálhatók (254.). A Bartók-temetés politikai retorikáját érdemes volna a korabeli sajtóanyag tartalomelemzésével megvizsgálni, a törvényszerüen visszatérő sajátságok alapján jól igazolható volna az implicit információk megléte, vagyis például a Bartók személyére, a fasizmusra, a romániai viszonyokra és egyebekre, mint tartalomelemzési kategóriákra összpontosítva.

Susan Gal tanulmányainak kötete - amint a fentebb kiragadott néhány példa is mutatja - gazdagítja a magyar nyelvvel szorosabban érintkező szociolingvisztikát, továbbá ösztönözheti annak e tekintetben kiszélesíthető kutatásait kiváltképpen a kisebbségben élő magyar népcsoportokra gondolva. A kötet címe ellenére el kell mondani, hogy nem a nyelvnek van politikája (politiké tekhné), hanem a társadalom, a közösség egésze vagy valamely része saját céljai elérésére használja valamiképpen a nyelve(ke)t. Ebben használatban esetlegesen megtalálhatók olyan jellegzetességek, amilyeneket a tágabb értelemben vett antropológia hasznosítani tud.

(Susan Gal: A nyelv politikája - Nyelvi antropológiai tanulmányok. Szerkesztette: Vančo Ildikó, Kozmács István, forditotta: Bács Ódry Erzsébet, Balogh Erzsébet, Barát Erzsébet et al. Nyitra-Nitra: Nyitrai Konstantin Filozófus Egyetem Közép-Európai Tanulmányok Kara - Univerzita Konštantína v Nitre Fakulta Stredoeurópskych Štúdií, 2018, 354 o.)

Büky László

az MTA doktora Szegedi Tudományegyetem Bölcsészettudományi Kar Magyar Nyelvészeti Tanszék 